\title{
O RECURSO DE AGRAVO DE INSTRUMENTO E O JULGAMENTO DO TEMA N. 988 PELO STJ
}

\author{
Fernando Lage Tolentino ${ }^{1}$ \\ Escola Superior Dom Helder Câmara (ESDHC) \\ Gabrielle Pamplona Cunha ${ }^{2}$ \\ Escola Superior Dom Helder Câmara (ESDHC)
}

Artigo recebido em: 07/11/2019.

Artigo aceito em: 02/12/2019.

\section{Resumo}

Este artigo discorre sobre o julgamento,

razão da atecnia redacional pelo legispelo Superior Tribunal de Justiça, a respeito da natureza jurídica do rol legal de hipóteses de cabimento do recurso de agravo de instrumento, previsto no art. 1.015 do Código de Processo Civil vigente. O objetivo geral da pesquisa é analisar a tese de taxatividade mitigada do rol em análise, quando do julgamento do tema n. 988. Para tanto, faz-se necessária a análise das teses anteriormente debatidas pela doutrina e jurisprudência, quais sejam: (i) taxatividade do rol, devendo ocorrer interpretação restritiva de suas hipóteses; (ii) interpretação extensiva/analógica do rol, com ampliação pontual e casuística em determinadas situaçóes fáticas; e (iii) rol exemplificativo, em lador. Em termos metodológicos, o trabalho apresenta abordagem qualitativa e exploratória, sendo o método de pesquisa dedutivo-dialético, baseado na pesquisa bibliográfica e documental a respeito do tema. Em síntese conclusiva, verificou-se a relevância da tese da taxatividade mitigada com vistas à efetiva implementação da ampla defesa em grau recursal, não obstante eventual discricionariedade judicial na definiçấo do interesse recursal no caso concreto.

Palavras-chave: agravo de instrumento; irrecorribilidade em separado das decisóes interlocutórias; taxatividade mitigada.

1 Mestre em Direito Processual Civil pela Pontifícia Universidade Católica de Minas Gerais (PUC-MINAS). Especialista em Direito Digital e Compliance pelo Instituto Brasileiro de Mercado de Capitais (Faculdade IBMEC). Bacharel em Direito pela PUC-MINAS. Professor Assistente IV de Direito Processual Civil no curso de graduaçáo em Direito da ESDHC. Advogado. E-mail: fernandolagetolentino@gmail.com

2 Bacharel em Direito pela ESDHC. Advogada. E-mail: gabriellepamplonacunha16@gmail.com 


\section{INTERLOCUTORY APPEAL AND THE JUDGMENT OF THE THEME N. 988 BY THE STJ}

\section{Abstract}

This article deals with the judgment by the Superior Court of Justice regarding the nature of the legal list of hypotheses of interlocutory appeal, provided by the article 1.015 of the current Code of Civil Procedure. The general objective of the research is to analyze the mitigated taxativity thesis of the list under analysis, when judging the theme n. 988; therefore, it is necessary to analyze the theses previously debated by the doctrine and jurisprudence, which are: (i) taxativeness of the list, and there should be a restrictive interpretation of its hypotheses; (ii) extensivelanalog interpretation of the role, with occasional and case-by-case amplification in certain factualsituations; and (iii) an exemplary list, due to the incorrect wording of the legislation. In methodological terms, the work presents a qualitative and exploratory approach, being the deductive-dialectical research method, based on bibliographic and documentary research on the subject. In conclusion, it was verified the relevance of the mitigated taxativity thesis with a view to the effective implementation of the broad defense in the appellate degree, despite possible judicial discretion in the definition of the appeal interest in the specific case.

Keywords: interlocutory appeal; mitigated taxativity; separate irrecoverability of interlocutory decisions. 


\section{Introdução}

Não restam dúvidas que a entrada em vigor do Código de Processo Civil (CPC) de 2015 trouxe várias mudanças no sistema processual civil brasileiro. Não apenas mudanças paradigmáticas, que muito provavelmente são as mais importantes na busca por uma atuação mais democrática e eficiente dos órgãos jurisdicionais, mas também de ordem prática, que interferem no dia a dia dos mais diversos sujeitos processuais.

Entre essas modificaçóes, podemos indicar a alteração do regime de impugnação das decisôes interlocutórias como uma das mais impactantes.

O legislador do código vigente, rompendo com a lógica de impugnação imediata das decisões interlocutórias que vigorava no Código de Processo Civil de 1973, passou a adotar, ainda que parcialmente, o princípio da irrecorribilidade imediata das decisōes interlocutórias, com vistas a imprimir mais celeridade e economia processuais.

Extinguindo a figura do recurso de agravo retido, estabeleceu um rol pretensamente taxativo de hipótese de cabimento do recurso de agravo de instrumento no art. 1.015 do CPC. Em princípio, a impugnação imediata de decisóes intermediárias somente seria possível nas hipóteses ali indicadas, com a finalidade de diminuir o "grande volume" de recursos a serem processados e julgados perante os tribunais pátrios.

Todavia, antes mesmo da entrada do CPC em vigor, a doutrina iniciou intenso debate a respeito da natureza jurídica de tal rol. A despeito da clara vocação para taxatividade do rol legalmente instituído, a prática forense logo mostrou sua insuficiência, fruto de péssima técnica legislativa de enunciação casuística. Com a entrada em vigor do Código, o debate se aprofundou, com a participação da jurisprudência dissonante dos vários tribunais pátrios, gerando elevado grau de divergência de posicionamentos a respeito do tema.

Este ensaio tem como objetivo analisar o desenvolvimento da discussão do tema a respeito da natureza jurídica do rol de hipóteses de cabimento do recurso de agravo de instrumento perante o Superior Tribunal de Justiça, tribunal constitucionalmente responsável pela uniformização da interpretação e aplicação das normas infraconstitucionais federais.

Para entendermos de maneira adequada o resultado do julgamento do tema n. 988 pelo STJ, que definiu a chamada taxatividade mitigada do rol em análise, devemos, primeiro, compreender os motivos que levaram o legislador a modificar o sistema de impugnação das decisôes interlocutórias até então vigente, bem como expor os posicionamentos teóricos criados doutrinariamente a respeito do rol, 
com destaque para o entendimento que havia se consolidado majoritariamente sobre a possibilidade de interpretação extensiva/analógica do rol do art. 1.015.

\section{$1 \mathrm{O}$ sistema de recorribilidade das decisóes interlocutórias na vigência do Código de Processo Civil de 2015}

Antes de analisarmos propriamente o julgamento do tema n. 988 pelo STJ, faz-se necessário o estudo, ainda que sucinto, do sistema de recorribilidade das decisóes interlocutórias adotado pelo Código de Processo Civil vigente, uma vez que a adequada compreensão desse sistema será o ponto de partida para o desenvolvimento da discussão doutrinária e jurisprudencial a respeito da possibilidade ou não de abertura do rol de hipóteses legais de cabimento do recurso de agravo de instrumento.

\subsection{O princípio da irrecorribilidade imediata ou em separado das decisóes interlocutórias no Código de Processo Civil: origem, conceito e previsáo legislativa}

O princípio da irrecorribilidade imediata, ou em separado das decisóes interlocutórias consoante, menciona Assis (2017, p. 606), se originou diretamente do princípio da oralidade, que visa à simplicidade e à fluidez dos atos procedimentais. Araken de Assis (2017, p. 607) explica, ainda, que tal princípio, no sistema processual brasileiro, foi previsto, primeiramente, pelo CPC de 1939.

Segundo o mesmo autor, o princípio em estudo tem por objetivo precípuo impedir que as várias decisóes proferidas pelo magistrado dentro de um mesmo processo, sem finalizá-lo, sejam impugnadas em oportunidades diferentes, visando, assim, a concentração dos atos processuais e a valorização dos princípios da celeridade e economia processual (ASSIS, 2017).

De acordo com Humberto Theodoro Júnior (2015, p. 962) por esse princípio "não se tolera a interrupção da marcha processual para apreciação de recursos contra decisóes de questôes incidentais"; em outras palavras, tal princípio veda que as decisóes interlocutórias proferidas durante o curso do processo, sejam analisadas separadamente da decisão que resolve definitivamente o mérito do processo.

Nesse diapasão, o legislador, no Código de Processo Civil de 2015, visando simplificar a sistemática da recorribilidade das decisôes interlocutórias e diminuir o manejo do recurso de agravo de instrumento nos tribunais, adotou, ainda que parcialmente, o princípio em análise, extinguindo a figura do agravo retido 
previsto no CPC de 1973 e elencando no art. 1.015 do atual diploma processual as hipóteses de cabimento do agravo de instrumento. Em princípio, caso a decisão não conste do mencionado rol, o seu reexame será feito por meio do recurso de apelação, nos termos do $₫ 1^{\circ}$ do art. 1.009 do CPC.

Assim, conforme as sábias lições de Neves (2017, p. 1.598-1.599), o princípio em análise foi significativamente ampliado no CPC de 2015 em relação ao CPC de 1973, visto à extinção da modalidade do agravo retido e a enumeração das hipóteses de cabimento do agravo de instrumento de modo, ao menos em tese, taxativo.

Todavia, em que pese a nobre intenção do legislador, a adoção do princípio da irrecorribilidade imediata das decisôes interlocutórias pelo atual Código de Processo Civil foi alvo críticas pela doutrina.

$\mathrm{Na}$ opinião de Assis, por exemplo, a adoção do princípio da irrecorribilidade imediata pelo legislador do CPC de 2015 significou verdadeiro retrocesso processual, pois ao afirmar que (2017, p. 614) "o CPC de 2015, quanto ao cabimento do agravo de instrumento, retornou ao regime do CPC de 1939”, quis dizer, pois, que, de acordo com a sistemática do CPC d

e 1939, essa restrição e o excesso de simplicidade dos atos processuais, algumas vezes, poderão diminuir a importância da recorribilidade das decisóes interlocutórias, além de causar prejuízos irreparáveis às partes.

Em síntese, como analisado, o legislador adotou parcialmente o princípio da irrecorribilidade imediata, buscando concentrar a atividade recursal ao final do trâmite processual em primeira instância, em uma tentativa de priorizar a simplicidade dos atos processuais e os princípios da celeridade e da economia processual. Todavia, conforme se verá nos próximos tópicos, essa opção não foi tão acertada quanto pensou o legislador.

\subsection{Do cabimento do recurso de agravo de instrumento no Código de Processo Civil: da pretensa taxatividade do rol previsto no art. 1.015}

$\mathrm{O}$ recurso de agravo de instrumento consiste no recurso destinado à impugnação das decisōes interlocutórias.

O conceito de decisão interlocutória foi definido pelo CPC de 2015 por exclusão, pois, de acordo com seu art. $203, \$ 2^{\circ}$, decisão interlocutória consiste em "todo pronunciamento judicial de natureza decisória" que não caracterize sentença.

Como bem explica Assis (2017, p. 622), as decisóes interlocutórias são aquelas 
que vão "desembaraçando o caminho, preparando o julgamento do mérito". Já a sentença, como regra, é o ato decisório que busca encerrar a etapa cognitiva ou executória de um procedimento, verificada ou não a análise do mérito.

Feitas tais consideraçóes passemos à análise propriamente dita da sistemática de recorribilidade das decisóes interlocutórias no Código de Processo Civil.

Pois bem, o Código de Processo Civil de 2015 inaugurou uma nova metodologia com respeito ao recurso de agravo de instrumento, elencando em seu art. 1.015 as hipóteses de cabimento do referido recurso.

Desse modo, segundo previsto pelo atual CPC, são recorríveis, de maneira imediata, por meio do agravo de instrumento as decisóes interlocutórias que versarem sobre tutelas provisórias; o mérito do processo; a rejeição da alegaçáo de convenção de arbitragem; o incidente de desconsideração da personalidade jurídica; a rejeição do pedido de gratuidade da justiça ou acolhimento do pedido de sua revogação; a exibiçáo ou posse de documento ou coisa; a exclusão de litisconsorte; a rejeição do pedido de limitação do litisconsórcio; a admissão ou inadmissão de intervenção de terceiros; a concessão, modificação ou revogação do efeito suspensivo aos embargos à execução; a redistribuição do ônus da prova nos termos do art. $373, \$ 1^{\circ}$, bem como as decisóes interlocutórias proferidas na fase de liquidação ou cumprimento de sentença; no processo de execução e no processo de inventário, além de outros casos previstos em lei.

Ressalta-se que nos casos previstos pelo art. 1.015 ocorrerá a preclusão da matéria, caso não seja manejado tempestivamente o recurso de agravo de instrumento.

Quanto as demais decisóes interlocutórias que forem proferidas no curso do procedimento de conhecimento (seja ele comum ou especial), nos termos do $\$ 1^{\circ}$ do art. 1.009 , náo serão cobertas pela preclusão, devendo ser questionadas mediante recurso de apelação, pela via de preliminares em sede de razóes ou contrarrazóes.

Logo, no que tange à nova regra, Theodoro Júnior (2015, p. 1.010) explica que "se a parte prejudicada pela decisão interlocutória for vencida na ação, deverá arguir a matéria em preliminar de apelação, sendo a parte contrária intimada para contrarrazoar" em 15 dias. Contudo, se a parte for a vencedora, a impugnação deverá ser feita nas contrarrazóes de eventual apelaçáo interposta pela parte adversária. Nesse caso, "o vencedor manejaria, na verdade, um recurso eventual e subordinado, visto que só seria apreciado caso o recurso do vencido fosse provido para reformar a sentença” (THEODORO JÚNIOR, 2015, p. 1.010). Vale ressaltar que por medida de isonomia processual, o apelante também será intimado para responder em até 15 dias, em conformidade com previsão do $₫ 2^{\circ}$ do art. 1.009 .

No que diz respeito à redaçáo do $₫ 1^{\circ}$ do art. 1.009, Daniel Amorim 
Assumpção Neves (2017, p. 1643) destaca que este não é digno de elogios, uma vez que náo basta as partes alegarem seu inconformismo com a decisão, devendo fazer de maneira fundamentada. Ademais, não se trata das decisóes proferidas no processo de conhecimento, mas sim das decisôes interlocutórias prolatadas no curso do procedimento. Neves (2017) também critica ser bastante curiosa a opção do legislador em prever dois recursos completamente distintos para se recorrer de um mesmo tipo de decisão, qual seja as interlocutórias. Para ele, na prática, há uma incongruência significativa na escolha do legislador, visto que o recurso de apelação apresenta regras formais e procedimentais bastante distintas do recurso de agravo de instrumento.

Outro problema que é apontado por Neves (2017) com referência ao dispositivo em comento é que, tendo em vista que a decisão interlocutória deve ser impugnada por meio da preliminar de apelação, a sua análise depende diretamente da admissibilidade desse recurso. Assim, caso a apelação seja inadmitida, o reexame da decisão interlocutória restará integralmente prejudicado, uma vez que o Tribunal não pode conhecer parte de recurso inadmitido. Para Neves (2017), esse é um dos maiores problemas a ser enfrentado pelas partes no processo, tendo em vista a possibilidade de violação de direitos fundamentais das partes, por exemplo, o princípio da ampla defesa.

Portanto, percebe-se que a nova sistemática de recorribilidade das decisóes interlocutórias no CPC de 2015 buscou concentrar, a um só tempo, o reexame destas. Entretanto, como explicitado, não há como afirmar que tal escolha foi sabiamente adotada pelo legislador. No próximo tópico, o leitor verá que, ao contrário da intenção do criador da norma, a adoção do princípio da irrecorribilidade, do modo como foi concretizado, está longe de alcançar a perfeição técnica processual.

\subsection{Críticas doutrinárias acerca da pretensa taxatividade das hipóteses de cabimento do recurso de agravo de instrumento: incongruências e consequências práticas da taxatividade do rol do art. 1.015}

O Código de Processo Civil de 2015 inaugurou uma nova fase do Direito Processual Civil brasileiro, embora tenha trazido inovaçóes positivas, por exemplo, a primazia pelo julgamento do mérito ou a valorização dos precedentes normativos, carrega também pontos negativos. Entre os pontos negativos do novo diploma legal, destaca-se um que foi e continua sendo alvo de muitas críticas entre advogados, especialistas e doutrinadores, qual seja: a recorribilidade das decisóes interlocutórias no atual diploma processual. 
Segundo Pablo Freire Romão (2016), a recorribilidade das decisóes interlocutórias sempre foi um problema do Direito Processual Civil, pois, desde o CPC de 1939 o legislador vem tentando criar maneiras de evitar o atulhamento de recursos de agravo de instrumento no âmbito dos tribunais.

Assim, com tal objetivo em mente, o legislador do CPC de 2015 adotou, ainda que parcialmente, o princípio da irrecorribilidade imediata das decisóes interlocutórias e elencou de modo pretensamente taxativo as decisóes imediatamente recorríveis por agravo de instrumento. Todavia, conforme se verá adiante, essa escolha feita pelo legislador não restou isenta de falhas, visto a gama de críticas feitas pelos especialistas. Vejamos.

Analisando o rol do art. 1.015, percebe-se que o legislador restringiu a adoçáo do princípio da irrecorribilidade imediata das decisôes interlocutórias apenas à fase de conhecimento, não se aplicando essa regra as demais fases processuais, bem como ao procedimento de inventário, tendo em vista o disposto no parágrafo único do artigo em comento.

Sobre esse aspecto Theodoro Júnior et al. (2015) entendem que o legislador do CPC de 2015 acabou criando uma situação de extrema quebra de isonomia entre os tipos de procedimentos, construindo um rol totalmente incoerente, haja vista que uma mesma decisão poderia ser ou não recorrível por meio do recurso de agravo de instrumento a depender do procedimento ou fase processual.

Assim, nos dizeres de Humberto Theodoro Júnior et al. (2015, p. 32):

Cria-se um modelo nada coerente ao se restringir a recorribilidade das interlocutórias às hipóteses expressamente previstas, no procedimento comum, e permite uma recorribilidade ilimitada das interlocutórias via agravo em determinados procedimentos/ fases. Aqui não se questiona o fundamento da exceção (ausência de sentença apelável a viabilizar a recorribilidade diferida), mas, desde já, induz situaçôes de que uma mesma decisão, a depender do procedimento, caiba ou não recorribilidade imediata.

Igualmente, para Neves (2017, p. 1659-1660), o legislador não foi coerente ao impor a taxatividade das hipóteses de cabimento do recurso de agravo de instrumento. De acordo com esse doutrinador, ao contrário do que o legislador pensa, o agravo de instrumento não é o responsável pela morosidade do sistema recursal, pois "há tribunais que funcionam e outros não, e em todos eles se julgam agravos de instrumento". Ainda, segundo Neves (2017, p. 1660), essa limitação no que diz respeito ao cabimento do recurso de Agravo de Instrumento é "flagrantemente violadora dos princípios do devido processo legal e da ampla defesa”, resultando em prejuízos processuais para as partes. 
Destarte, outra observação importante é feita por Romão (2016), ao informar que em pesquisa realizada pela UFMG e UFBA ficou concluído que a mudança não trará resultados significativos para o trâmite processual, tendo em vista que a partir de um levantamento realizado pelo TJBA ficou demonstrado que as hipóteses de irrecorribilidade imediata representam menos de $12 \%$ das decisóes em que foi interposto, naquele tribunal, o recurso de agravo de instrumento.

Conforme enunciado por Theodoro Júnior et al. (2015, p. 33):

A partir da pesquisa era possível depreender que a técnica legislativa casuística ou regulamentar, posta no anteprojeto e mantida no Senado, não se adaptaria adequadamente à hipótese, sendo mais conveniente a mantença da cláusula geral permissiva do agravo, eis que o modelo de rol casuístico de hipóteses de cabimento não abarcaria todas as situaçôes que evitariam a futura anulação da sentença, criando retrabalhos procedimentais que contrariam a própria premissa de máximo aproveitamento processual.

Romão (2016, p. 245) concorda com o pensamento supraexposto ao dizer que a técnica utilizada pelo legislador "não se adapta à realidade forense", pois, também, em sua opinião, seria melhor que o legislador tivesse mantido a cláusula geral permissiva do agravo de instrumento constante do CPC de 1973.

Todavia, há quem pense diferente, pois para Neves (2017, p. 1660) "o legislador deveria ter criado um rol legal exauriente de náo cabimento do recurso [...] teria sido muito mais adequado se tivesse discriminado de forma pontual o não cabimento do agravo de instrumento em vez de prever seu cabimento".

Ademais, Mello et al. (2016) compartilham do mesmo pensamento que os juristas Humberto Theodoro Júnior, Dierle Nunes, Alexandre Melo Franco Bahia, Flávio Quinaud Pedron e Pablo Freire Romão, ao afirmar que o legislador, embora tenha tentado abarcar todas as decisóes que possam gerar prejuízos imediatos para as partes, não foi capaz de cumprir o intencionado, pois, em alguns casos, como no de indeferimento de produção de provas, com exceção do inc. VI do art. 1.015, aguardar o recurso de apelaçáo poderia ser completamente prejudicial, levando, até a anulação dos atos processuais já praticados.

A título de exemplo, Mello et al. (2016) explicam que deixar para questionar a decisão interlocutória que versar sobre o indeferimento de provas pericial ou testemunhal para a preliminar de apelação configurara uma situação extremamente prejudicial para as partes litigantes, bem como para o andamento processual a depender do caso, pois imagine-se "a hipótese que a prova pericial deve ser produzida imediatamente, sob pena de perecimento, como no caso de um edifício 
incendiado prestes a ruir" ou ainda a "hipótese em que a oitiva da testemunha faz-se urgente, como no caso de vítima de doença terminal, ou até mesmo hipótese em que se faça necessária a acareação das testemunhas".

Nas palavras exatas de Mello et al. (2016):

Caso a prova, de fato, seja imperiosa para o deslinde da questâo e sua produção, por qualquer razão, deva se dar de imediato, interpretando-se nấo caber agravo de instrumento em face da decisão que a indefere, poderá ocorrer à decretação de invalidade de todo o processo quando do julgamento da apelaçấo ou nas contrarrazóes respectivas, ou ainda, a impossibilidade material de produção daquela prova, em razão do seu perecimento.

Desse modo, percebe-se que nessas hipóteses, por exemplo, aguardar o momento processual de interposição do recurso de apelação pode acabar indo de encontro ao objetivo do legislador em imprimir maior celeridade processual, visto que se a produçáo da prova for essencial para o deslinde do feito, o relator ou o órgão colegiado, no momento de julgar o recurso de apelação, anulará todos os atos processuais praticados que tenham ligação com a prova não produzida, para que esta seja realizada, retornando os autos para a primeira instância.

Lado outro, além de ser extremamente onerosa para a duração razoável do processo, essa omissão legislativa constitui inequívoca hipótese de cerceamento de defesa, considerando que, em casos como esses, por exemplo, impedindo a parte de recorrer imediatamente, poderão acabar inviabilizando a chance desta de comprovar as suas alegaçóes, ou seja, resultará na inutilidade prática do recurso de apelaçáo no tocante à recorribilidade das decisóes interlocutórias.

Compartilhando desse pensamento, Neves (2017) concorda que as decisóes que versarem sobre o indeferimento de provas, em geral, deveriam constar no rol de decisões agraváveis, ao afirmar que não é plausível com os princípios da celeridade e economia processual a anulação dos atos processuais, por ter o legislador se omitido em prever como hipótese de cabimento de recurso imediato as decisôes que indeferem o pedido de produção de prova oral, por exemplo.

Além de configurar hipótese inequívoca de violação ao direito fundamental à ampla defesa, no que tange aos aspectos recursal e probatório, Neves acredita que (2017) o legislador constituiu uma falsa vantagem de celeridade e economia processual, visto que se houver acolhimento da preliminar de apelaçáo, os atos praticados até então e que dependam da análise da questâo incidental serão todos anulados e refeitos.

Assim, de acordo com os ensinamentos de Neves (2017, p. 1.660): 
Não é difícil imaginar o estrago que o acolhimento da impugnação de decisão interlocutória nesse momento procedimental ocasiona ao procedimento, ao anular todos os atos praticados posteriormente à decisão interlocutória impugnada. Basta imaginar um processo no qual a prova pericial foi indeferida, a parte nẫo pode agravar e alegar o cerceamento de defesa na apelação. Depois de longo lapso temporal, quando o tribunal de segundo grau finalmente enfrenta e julga a apelaçáo, reconhece que houve um cerceamento de defesa. Voltam-se os autos ao primeiro grau para a produção da prova pericial, sendo no mínimo a sentença anulada. É realmente concernente com os princípios processual e da duração razoável do processo de tal ocorrência?

Por fim, outro ponto preocupante que vinha sendo levantado por alguns juristas, como Jayme e Santos (2011), é a possibilidade do uso anômalo do mandado de segurança como sucedâneo recursal, haja vista que de acordo com o art. 5 da Lei 12.016, das decisóes irrecorríveis ou recorríveis por recursos desprovidos de efeito suspensivo é cabível sua impugnação por meio do mandado de segurança. Desse modo, Jayme e Marina Santos (2011, p. 153-154) apontam que:

$\mathrm{O}$ projeto do novo $\mathrm{CPC}$ dá ensejo, portanto, à substituição do agravo de instrumento pelo mandado de segurança contra ato judicial. $\mathrm{O}$ fato de utilizar uma ação constitucional em substituição a um recurso, por si só, já atentaria contra a efetividade do processo, porquanto seu procedimento é mais oneroso. Ademais, o que é mais grave e atentatório à efetividade processual, é o fato de que sendo de competência originária dos tribunais, o acórdão que julgar o mandado se segurança, se denegatória a ordem, pode ser impugnado mediante recurso ordinário, o que possibilitará o reexame da matéria fática pelo Superior Tribunal de Justiça.

Senso assim, tem-se que, de fato, a adoção do princípio da irrecorribilidade imediata das decisóes interlocutórias pelo Código de Processo Civil de 2015 não foi a mais acertada, uma vez que, embora o objetivo do legislador tenha sido o melhor possível com referência à razoável duração do processo, o que se conseguiu foi exatamente o contrário, ou seja, piorar a situação do recorrente, fazendo o trâmite recursal ser ainda mais remansado.

Desse modo, diante da possibilidade de se causar prejuízos irreparáveis para as partes, bem como para a razoável duração do processo, o Superior Tribunal de Justiça (STJ), conforme o leitor verá nos próximos tópicos, posicionou-se em dois 
momentos diferentes a respeito da natureza jurídica do rol de decisóes agraváveis. Ressalta-se que apenas no segundo momento restou definitiva qual é a natureza jurídica do rol de decisóes agraváveis previsto no novo Código de Processo Civil.

\section{O julgamento do Resp n. 1.679.909 pelo Superior Tribunal de Justiça e a possibilidade de interpretaçáo extensiva do rol de hipóteses de cabimento do agravo de instrumento}

Inicialmente, antes de analisarmos o conteúdo do acórdão proferido no Recurso Especial n 1.679.909, necessário se faz a explicação, de maneira sucinta, das três teorias que existiam dentro da doutrina sobre a natureza jurídica do rol de decisóes agraváveis, antes mesmo da entrada em vigor do atual Código de Processo Civil.

Destaca-se que a polêmica que envolvia tal discussão tinha inteira ligação com as possíveis consequências práticas que o rol, da maneira como foi sistematizado pelo legislador, causaria no âmbito processual.

Pois bem, a primeira corrente doutrinária, segundo informado por Nunes et al. (2018) era seguida por Marcelo Machado, Luiz Rodrigues Wambier, Teresa Arruda Alvim, Antônio Notariano Jr., Eduardo Talamini, Igor Guilhen Cardoso, Humberto Theodoro Júnior, Alexandre Câmara Freitas, Nelson Nery Junior e Rosa Maria de Andrade Nery. Tais autores entendiam que o rol de decisóes agraváveis era taxativo, mas sem possibilidade de interpretação extensiva ou analógica, ou seja, para eles deveria ser respeitada a literalidade da norma e a vontade original do legislador. Assim, as decisóes que não foram incluídas ao rol do dispositivo em comento, ou seriam objeto de preliminar de apelação/contrarrazóes ou de mandado de segurança.

Já a segunda corrente doutrinária, também conforme informado por Nunes, Aragão e Barbosa (2018), foi capitaneada por Fredie Didier Jr. e Leonardo Carneiro da Cunha que sustentavam a ideia de que, apesar do rol de decisóes agraváveis ser taxativo, não excluía a possibilidade de as hipóteses previstas serem interpretadas de maneira extensiva ou analógica. O pilar que justificativa a adoção de tal corrente era o risco que se tinha de "ressuscitar o uso anômalo e excessivo do mandado de segurança contra ato judicial” (DIDER JR.; CUNHA, 2016, p. 211). Assim, de acordo com os autores, de fato, as hipóteses de cabimento do recurso de agravo de instrumento são taxativas, contudo, essa taxatividade não constitui um impeditivo para que o rol de decisóes agraváveis possa ser interpretado de forma ampliativo-extensiva; pois, ainda que taxativas as hipóteses de cabimento, seria 
perfeitamente possível a interpretaçáo extensiva dos tipos previstos no art. 1.015. Destaca-se, ainda, que esta corrente também foi seguida pelos processualistas Marinoni, Arenhart e Mitidiero (2016), pois, para eles, embora o rol do art. 1.015 tenha sido construído para ser taxativo, não havia que se excluir a possibilidade de uma interpretação extensiva ou analógica do dispositivo.

Outro autor que também seguiu essa segunda corrente foi o professor Daniel Amorim Assumpção Neves (2017), ao afirmar que a maneira de se evitar o uso anômalo do mandado de segurança seria a possibilidade de se interpretar o rol do art. 1.015 de modo ampliativo e analógico.

Por fim, minoritariamente, uma terceira interpretação doutrinária a respeito da natureza jurídica do rol do art. 1.015, defendida por autores como José Rogério Cruz e Tucci (2017) e William Santos Ferreira (2017), defendia que estaríamos diante de um rol de taxatividade fraca, em virtude de sua patente incompletude, o que acabaria por tornar o rol apenas exemplificativo.

Visto isso, diante da divergência existente, a $4^{\mathrm{a}}$ Turma do Superior Tribunal de Justiça (STJ), em novembro de 2017, visando evitar prejuízos irreparáveis as partes e ao andamento processual, quando do julgamento do Recurso Especial n. 1.679.909 autorizou a interposição do recurso de agravo de instrumento em face de decisóes interlocutórias que versarem sobre competência absoluta ou relativa, por interpretação analógica ou extensiva do inc. III do art. 1.015, adotando, assim, a segunda corrente.

A causa de origem versava sobre a admissibilidade do recurso de agravo de instrumento contra decisão que indeferiu a exceção de incompetência territorial (relação de consumo), oposta sob a égide do CPC/1973 e julgada já sob a vigência do $\mathrm{CPC} / 2015$ sob a alegaçáo de que na vigência do atual diploma processual a decisão não comportava mais o agravo de instrumento.

Como se verá no acórdão da $4^{\mathrm{a}}$ Turma do Superior Tribunal de Justiça, além de o caso ser regido pelo CPC de 2015, tendo em vista a data de publicação da decisão, a questão posta em análise ainda sim era impugnável pelo recurso de agravo de instrumento, haja vista a possibilidade de se interpretar de maneira extensiva ou analógica a hipótese prevista no inc. III do art. 1.015. Confira-se parte do teor do julgado:

[...] Nessa ordem de ideias, apesar de náo ser previsto expressamente no rol do art. 1.015, penso que a decisão interlocutória, relacionada à definiçấo de competência continua desafiando recurso de agravo de instrumento, por uma interpretação analógica ou extensiva da norma. Deveras, a possibilidade de imediata recorribilidade da decisão advém de exegese lógico-sistemática do 
diploma, inclusive porque é o próprio Código que determina que o "juiz decidirá imediatamente a alegação de incompetência ( $\$ 3^{\circ}$ do art. 64)” (BRASIL, 2017).

\section{Continuou:}

Evitam-se, por essa perspectiva: a) as inarredáveis consequências de um processo que tramite perante um juízo incompetente (passível até de rescisória - art. 966, II, CPC); b) o risco da invalidação ou substituição das decisões (art. $64, \S 4^{\circ}$, primeira parte); c) o malferimento do princípio da celeridade, a se exigir que a parte aguarde todo o trâmite em primeira instância para ver sua irresignação decidida tão somente quando do julgamento da apelação; d) tornar inócua a discussão sobre a (in)competência, já que os efeitos da decisão proferida poderão ser conservados pelo outro juízo, inclusive deixando de anular os atos praticados pelo juízo incompetente, havendo, por via transversa, indevida "perpetuação" da competência; e) a angústia da parte em ver seu processo dirimido por juízo que, talvez, não é o natural da causa (BRASIL, 2017).

Finalizou afirmando que:

Trata-se de interpretação extensiva ou analógica do inciso III do art. 1.015 - "rejeiçẫo da alegação de convenção de arbitragem" -, já que ambas possuem a mesma ratio -, qual seja afastar o juízo incompetente para a causa, permitindo que o juízo natural e adequado julgue a demanda (BRASIL, 2017).

Sendo assim, o Superior Tribunal de Justiça, segundo Nunes, Aragão e Barbosa (2018), visou, ao possibilitar a interpretaçấo extensiva ou analógica do inc. III do art. 1.015, impedir os efeitos negativos que poderiam ocorrer no processo, caso um juiz incompetente continuasse, até o momento de julgar a apelação, conduzindo o procedimento.

Nas exatas palavras de Nunes, Aragão e Barbosa (2018):

Tal entendimento, conforme decisão colegiada, visa possibilitar a recorribilidade imediata e célere de decisōes que definam competência, haja vista as graves consequências decorrentes da tramitaçáo e julgamento do processo por juízo incompetente e a inocuidade de sua análise no momento do julgamento da preliminar de apelação. 
Assim, pode-se dizer que o posicionamento da 4 a Turma do Superior Tribunal de Justiça supramencionado abriu caminho para que outros incisos do art. 1.015 também pudessem ser interpretados de modo extensivo ou analógico. Tomamos por exemplo o acórdão proferido pela 2a Turma desta corte, no Recurso Especial n. 1.694.667/PR, em dezembro de 2017, que permitiu a impugnaçáo, por meio do recurso de Agravo de instrumento, da decisão que indefere a concessão de efeito suspensivo aos embargos do executado. A fundamentação do acórdão, conforme se verá, se pautou, justamente, na possibilidade de interpretação extensiva de uma das hipóteses previstas no rol do artigo retromencionado, qual seja aquela prevista no inc. X.

Veja-se parte do teor do julgado:

[...] Em uma interpretaçáo literal e isolada do art. 1.015, X, do CPC, nota-se que o legislador previu ser cabível o Agravo de Instrumento contra as decisōes interlocutórias que concederem, modificarem ou revogarem o efeito suspensivo aos Embargos à Execução, deixando dúvidas sobre qual seria o meio de impugnação adequado para atacar o decisum que indefere o pedido de efeito suspensivo aos Embargos à Execução. A situaçăo dos autos reclama a utilização de interpretação extensiva do art. 1.015, X, do CPC/2015. [...] Em que pese o entendimento do Sodalício $a$ quo de que o rol do citado art. Da nova lei processual é taxativo, não sendo, portanto, possível a interposiçấo de Agravo de Instrumento, nada obsta a utilização da interpretação extensiva. [...] Dessa forma, deve ser dada interpretaçáo extensiva ao comando contido no inciso X do art. 1.015 do CPC/2015 para que se reconheça a possibilidade de interposiçấo de Agravo de Instrumento nos casos de decisão que indefere o pedido de efeito suspensivo aos Embargos à Execução (BRASIL, 2017).

Logo, percebe-se que o Superior Tribunal de Justiça ao julgar os Recursos Especiais n. 1.679.909/RS e n. 1.694.667/PR, adotando a corrente da possibilidade de interpretação extensiva das hipóteses previstas no art. 1.015, buscou evitar diversos prejuízos processuais que a taxatividade, imposta pelo legislador, no tocante à recorribilidade imediata das decisóes interlocutórias no atual CPC, poderia vir a causar para as partes, bem como ao trâmite processual, conforme amplamente discorrido nos tópicos anteriores.

Entretanto, houve quem discordasse desse posicionamento, por acreditar que o método de interpretação extensiva ofereceria um risco ao princípio da segurança jurídica, visto que náo havia limites pré-fixados para o uso de tal método, 
podendo apresentar "sérios riscos de extrapolação e de decisionismos que mitigam a previsibilidade ao sistema recursal” (NUNES; ARAGÁO; BARBOSA, 2018).

Ainda, a respeito do posicionamento do Superior Tribunal de Justiça, Nunes, Aragão e Barbosa (2018) afirmam que o método da interpretação extensiva configura um risco "para o sistema preclusivo e, consequentemente, à segurança jurídica”, considerando que ao se aumentar as hipóteses de recorribilidade imediata por tal método, não se saberá o que preclui ou não de imediato, indo de encontro ao princípio da segurança jurídica processual. Além disso, Nunes, Aragão e Barbosa (2018) apontam "que muitos profissionais passarão a agravar de qualquer decisão a fim de se evitar a configuração da preclusão, gerando-se, com isso, o efeito reverso à eficiência procedimental.

A respeito disso, Ronaldo Kochem (2018) entende que a decisão da $4^{\mathrm{a}}$ Turma do Superior Tribunal de Justiça "representa uma quebra de confiança, carecedora de tutela". Porém, acredita que os efeitos dela podem ser modulados, com a finalidade de recuperar a confiança do tutelado.

Assim, nas exatas palavras de Kochem (2018):

[...] nada impede que os magistrados de casos futuros tutelem a confiança do jurisdicionado por meio do reconhecimento de regra de transição que receba o recurso de apelação sobre hipóteses fora do rol do artigo 1.015 do CPC, mesmo quando a jurisprudência se posiciona no sentido do cabimento de agravo de instrumento. Isso até que haja uma consolidação do entendimento.

Desse modo e por todo exposto, percebe-se que a adoção da interpretação extensiva das hipóteses previstas no art. 1.015, embora não tenha sido aceita de modo unânime pela doutrina, foi uma solução bastante razoável para os problemas pontuais e urgentes que foram surgindo ao longo da vigência do Novo Código de Processo Civil referente à recorribilidade das decisóes interlocutórias.

Destaca-se que tal soluçáo foi apresentada apenas temporariamente, pois em fevereiro de 2018 o Superior Tribunal de Justiça, buscando definir de uma vez por todas a natureza jurídica do rol de decisóes agraváveis, afetou, ao rito dos recursos repetitivos, os Recursos Especiais n. 1.696.396/MT e n. 1.704.520/MT, sob o tema n. 988. 


\section{O julgamento do Tema 988 pelo Superior Tribunal de Justiça e a fixaçáo da tese da taxatividade mitigada do rol de hipóteses de cabimento do agravo de instrumento}

Não obstante, o julgamento de alguns casos concretos pelas $2^{\mathrm{a}}$ e $4^{\mathrm{a}}$ Turmas do Superior Tribunal de Justiça, permitindo a interpretação extensiva/analógica do rol das hipóteses de cabimento, conforme relatado anteriormente, o mesmo tribunal, por meio de julgamento realizado pela $2^{\text {a }}$ Turma, interpretou de maneira taxativa o referido rol, segundo se pode observar do julgado do Recurso Especial n. $1.700 .308 / \mathrm{PB}$.

Diante da divergência interna ao próprio Tribunal Superior, bem como considerando a multiplicidade de casos concretos perante tribunais de segundo grau, o que potencializaria claramente grande volume de recursos especiais a serem interpostos, o Superior Tribunal de Justiça decidiu afetar ao sistema de julgamento de recursos repetitivos os Recursos Especiais n. 1.704.520/MT e n. 1.696.396/ MT, sob o tema n. 988, sob a relatoria da ministra Nancy Andrighi.

Em síntese, a ministra relatora, após expor a existência dos três posicionamentos interpretativos a respeito da natureza jurídica do rol previsto no art. 1.015 do CPC, supramencionados, defendeu tese distinta das anteriores, sendo em sua opiniáo que o rol teria, na verdade, uma espécie de taxatividade mitigada, sendo possível a interposição do recurso de agravo de instrumento em hipóteses não previstas no rol, todas as vezes que não houvesse interesse recursal na impugnação da decisão interlocutória em sede preliminar nas razóes ou contrarrazóes de eventual recurso de apelaçáo.

Em outras palavras, não ocorrendo a impugnaçáo imediata da decisão interlocutória mediante agravo de instrumento, seria possível que, no caso concreto um dano de difícil ou impossível reparação, fosse verificado em desfavor de uma das partes processuais, vez que a discussão tardia em sede de recurso de apelação seria inútil. Nos termos do voto da ministra Nancy Andrighi:

A tese que se propóe consiste em, a partir de um requisito objetivo - a urgência que decorre da inutilidade futura do julgamento do recurso diferido da apelaçáo -, possibilitar a recorribilidade imediata de decisóes interlocutórias fora da lista do art. 1.015 do $\mathrm{CPC}$, sempre em caráter excepcional e desde que preenchido o requisito urgência, independentemente do uso da interpretação extensiva ou analógica dos incisos do art. 1.015 do CPC, porque, como demonstrado, nem mesmo essas técnicas hermenêuticas 
são suficientes para abarcar todas as situaçóes.

[...]

Em última análise, trata-se de reconhecer que o rol do art. 1.015 do CPC possui uma singular espécie de taxatividade mitigada por uma cláusula adicional de cabimento, sem a qual haveria desrespeito às normas fundamentais do próprio $\mathrm{CPC}$ e grave prejuízo às partes ou ao próprio processo (BRASIL, 2018).

Ainda em seu voto, a ministra relatora abordou três questôes relevantes para a solução desse tema: (i) a preclusão ou não da decisão interlocutória em caso de uso do agravo de instrumento em hipótese não prevista no rol; (ii) a necessidade de modulação temporal dos efeitos da decisão tomada no tema n. 988; (iii) a possibilidade de utilização ou não do mandado de segurança como sucedâneo recursal em face de decisões interlocutórias não previstas no rol.

No que tange à questão da preclusão, a ministra Nancy Andrighi defendeu a tese de que somente ocorreria preclusão da matéria tratada na decisão interlocutória não arrolada legalmente, mas impugnada via agravo de instrumento, nos casos em que o recurso retromencionado fosse objeto de juízo de admissibilidade positivo pelo tribunal de segundo grau. Ou seja, caso o recorrente se utilizasse do recurso de agravo de instrumento em situação hipotética não prevista no rol do art. 1.015 do CPC e o tribunal de segundo grau não conhecesse do recurso, seria possível impugnar a decisão em sede preliminar nas razôes ou contrarrazóes do recurso de apelação.

Sobre a modulação temporal dos efeitos do julgamento do recurso repetitivo, a ministra relatora, com fulcro no art. 23 da Lei de Introdução às Normas do Direito Brasileiro, asseverou que a tese da taxatividade mitigada seria aplicável às decisões interlocutórias proferidas após a publicação do acórdão do tema n. 988.

Por fim, seguindo entendimento reiterado na jurisprudência dominante dos tribunais pátrios, em especial o Supremo Tribunal Federal, a ministra relatora entendeu não ser cabível a impetraçáo de mandado de segurança em face de decisões interlocutórias não previstas no rol do art. 1.015, uma vez que seria possível a utilização do recurso de agravo de instrumento em virtude da tese da taxatividade mitigada. Assim sendo, o uso do mandando de segurança como sucedâneo recursal ficaria adstrita às hipóteses já previstas no art. $5^{\circ}$ da Lei n. $12.016 / 2009$.

Logo após o voto da ministra relatora, a ministra Maria Thereza de Assis Moura pediu vistas, para posteriormente apresentar voto divergente.

Náo obstante, reconhecer a insuficiência das hipótese legais de cabimento do recurso agravo de instrumento, asseverando que o sistema de irrecorribilidade 
imediata das decisôes interlocutórias adotado pelo $\mathrm{CPC}$ vigente não fazia as decisões interlocutórias náo previstas no rol do art. 1.015 se tornarem irrecorríveis, verificando-se apenas a concentração/cumulação da atividade recursal no momento final do desenvolvimento do procedimento em primeiro grau, com vistas à implementação do princípio da razoável duração do processo, a ministra Maria Thereza de Assis Moura defendeu a taxatividade do rol, que deveria ser interpretado restritivamente, uma vez que não caberia ao Superior Tribunal de Justiça agir no lugar ou em substituição ao legislador.

Criticando a tese proposta pela ministra Relatora, a ministra Maria Thereza de Assis Moura afirmou que a tese da taxatividade mitigada deixaria grande espaço de subjetividade/discricionariedade nas máos dos tribunais de segundo grau, quando da análise daquilo que seria urgente ou náo, sendo certo que estaríamos diante de grave violação à segurança jurídica dos jurisdicionados.

Acompanharam o voto proferido pela ministra Nancy Andrigui os ministros Napoleão Nunes Maia Filho, Jorge Mussi, Luis Felipe Salomão, Benedito Gonçalves, Raul Araújo e Felix Fischer.

Acompanharam o voto divergente proferido pela ministra Maria Thereza de Assis Moura os ministros João Otávio de Noronha, Humberto Martins, Og Fernandes e Mauro Campbell Marques.

Desse modo, por maioria de votos, o Superior Tribunal de Justiça, por meio de sua Corte Especial, no julgamento do tema n. 988, definiu que o rol do art. 1.015 do CPC é de taxatividade mitigada, razão pela qual admite a interposição de agravo de instrumento quando se verifica a urgência decorrente da inutilidade do julgamento da questáo no recurso de apelação.

\section{Conclusão}

Mesmo antes da entrada em vigor do atual Código de Processo Civil, verificamos grande debate doutrinário a respeito da natureza jurídica do rol de hipóteses legais de cabimento do recurso de agravo de instrumento. Esse debate perdurou por mais de dois anos após o início da vigência do referido código, ampliando a discussão para a esfera jurisprudencial.

Como podemos observar, quatro teses foram defendidas: (i) taxatividade do rol, cuja interpretação deveria ser restritiva; (ii) rol exemplificativo, em razão da atecnia do legislador ao prever de modo insuficiente as hipóteses de uso do recurso de agravo de instrumento; (iii) rol taxativo, passível de interpretação extensiva/ analógica; e (iv) taxatividade mitigada, baseada na urgência em se recorrer de imediato de uma decisão interlocutória. 
A despeito de a tese da interpretação extensiva/analógica ter alcançado apoio majoritários entre os doutrinadores, podemos afirmar que ela era insuficiente, uma vez que nem todas as situaçôes fáticas que demandassem a interposição do recurso de agravo de instrumento de imediato seriam passíveis de derivação de uma das hipóteses legais previstas no rol do art. 1.015 do CPC. Um bom exemplo dessa insuficiência da tese seria a decisão interlocutória que indefere o processamento do feito em segredo de justiça, em hipótese fática em que o sigilo fosse indispensável para se resguardar a intimidade das partes processuais envolvidas. A partir de qual hipótese legal teríamos a interpretação extensiva? Claramente não haveria reposta positiva.

A tese da taxatividade mitigada fixada pela ministra Nancy Andrighi tem em seu favor a possibilidade de permitir o uso do recurso de agravo de instrumento de maneira mais abrangente e efetiva, fugindo da necessidade de correlação com uma das hipóteses legais previstas no CPC. Alegada e comprovada a ausência de interesse na impugnação da decisão interlocutória em sede preliminar nas razôes ou contrarrazôes de recurso de apelaçáo, o interessado pode manejar de imediato o recurso de agravo de instrumento, fora das hipóteses previstas no rol, em razão da possibilidade de ocorrência de um dano grave de difícil ou impossível reparação, assegurada assim a ampla defesa.

A fixaçáo do regime de preclusão nos termos do voto da ministra Relatora do tema n. 988 apresenta-se como satisfatório, evitando-se prejuízos para a parte que tentou agravar em hipótese fora do rol, mas cujo recurso não foi admitido, resguardado, então, o direito de impugnação em momento posterior. Deve-se destacar que a tese fixada passou a valer para decisóes interlocutórias proferidas a partir da publicação do acórdáo do recurso repetitivo, o que ocorreu em 19 de dezembro de 2018.

Entretanto, um ponto complexo merece uma análise mais detida ao longo dos próximos meses e anos, a fim de verificarmos se a orientação fixada pelo STJ foi a mais adequada.

Segundo muito bem exposto pela ministra Maria Thereza de Assis Moura em seu voto divergente, o critério de urgência, como definido no cerne da tese da taxatividade mitigada, pode abrir espaço para análises baseadas em subjetividades por partes dos tribunais de segundo grau, o que pode inviabilizar o objetivo de acesso efetivo à jurisdição fixado pelo voto vencedor da ministra relatora.

Encerramos este breve ensaio deixando algumas perguntas na mente do leitor: a tese da taxatividade mitigada não seria, na verdade, um retorno ao sistema de uso do agravo de instrumento previsto no art. 522 do Código de Processo Civil de 1973, que previa o cabimento do recurso em face de decisóes interlocutórias 
capazes de gerar lesão grave e de difícil reparação? Quais seriam os traços diferenciadores, se é que eles, porventura, existem? A ministra Maria Thereza de Assis Moura, ao temer a subjetividade interpretativa, estava fazendo referência aos problemas ocorridos na interpretação do termo "lesão grave de difícil reparação" presente na legislação revogada?

\section{Referências}

ASSIS, A. Manual dos recursos. 9. ed. São Paulo: Revista dos Tribunais, 2017.

BRASIL. Superior Tribunal de Justiça (2. Turma). Recurso especial 1694667/PR. Processual civil. Agravo de instrumento contra decisão que indeferiu pedido de concessão de efeito suspensivo aos embargos à execução. Possibilidade. art. 1.015, x, do cpc/2015. Interpretaçáo extensiva. isonomia entre as partes. Paralelismo com o art. 1.015, i, do cpc/2015. Natureza de tutela provisória. Recorrente: Jorge Yamawaki. Recorrido: Fazenda Nacional. Relator: Min. Herman Benjamin, 5 dez. 2017. Disponível em: https://ww2.stj.jus.br/processo/ revista $/$ documento $/$ mediado/?componente=ITA\&sequencial=1647838\&num_ registro $=201701896959 \&$ data $=20171218 \&$ formato $=$ PDF. Acesso em: 5 nov. 2019.

BRASIL. Superior Tribunal de Justiça (4. Turma). Recurso especial 1679909/RS. Recurso especial. processual civil. aplicação imediata das normas processuais. Tempus regit actum. Recurso cabível. Enunciado administrativo n. 1 do stj. Exceção de incompetência com fundamento no cpc/1973. Decisão sob a égide do cpc/2015. Agravo de instrumento náo conhecido pela corte de origem. direito processual adquirido. Recurso cabível. Norma processual de regência. Marco de definição. Publicação da decisão interlocutória. Recurso cabível. Agravo de instrumento. Interpretação analógica ou extensiva do inciso iii do art. 1.015 do cpc/2015. Recorrente: Claudia Medeiros Moreira Tomasi e outro. Recorrido: Cooperativa Agropecuária Petrópolis Ltda. Pia. Relator: Min. Luis Felipe Salomão, 14 de novembro de 2017. Disponível em: https://ww2.stj.jus.br/processo/ revista $/$ documento/mediado/?componente=ITA\&sequencial=1655954\&num_ registro $=201701092223 \&$ data $=20180201 \&$ formato $=$ PDF. Acesso em: 5 nov. 2019.

BRASIL, Superior Tribunal de Justiça (Corte especial). Recurso especial 1696396/ $M T$. Recurso especial representativo de controvérsia. Direito processual civil. Natureza jurídica do rol do art. 1.015 do cpc/2015. Impugnação imediata de decisóes interlocutórias náo previstas nos incisos do referido 
dispositivo legal. Possibilidade. Taxatividade mitigada. Excepcionalidade da impugnação fora das hipóteses previstas em lei. Requisitos. Recorrente: Ivone da Silva. Recorrido: Alberto Zuzzi. Relatora: Min. Nancy Andrighi, 19 dez. 2018. Disponível em: https://ww2.stj.jus.br/processo/revista/ documento $/$ mediado $/$ ?componente=ITA \&sequencial $=1731780 \&$ num registro $=201702262874 \&$ data $=20181219 \&$ formato $=$ PDF. Acesso em: 5 nov. 2019.

BRASIL. Superior Tribunal de Justiça. Recurso especial (2. Turma). Recurso especial 1700308/PB. Processual civil. Questáo afetada ao rito dos recursos repetitivos tendo como representativo da controvérsia o resp n. 1.704.250/mt. Afetação, contudo, desprovida de efeito suspensivo, modulando o disposto no inciso ii do art. $1.037 /$ cpc. Possibilidade, então, de análise do mérito do recurso especial presente. Agravo de instrumento. Descabimento. art. 1.015 do cpc/2015. Rol taxativo. Impossibilidade de interpretação extensiva. Não há similaridade entre os institutos. Competência do juízo e rejeição de juízo arbitral para a extensão pretendida. Opção político-legislativa do congresso nacional. Recorrente: Jose Vicente Meira de Vasconcelos. Recorrido: Instituto Brasileiro do Meio Ambiente e dos Recursos Naturais Renováveis - IBAMA. Relator: Min. Herman Benjamin, 23 maio 2018. Disponível em: https://ww2.stj.jus.br/processo/ revista $/$ documento/mediado/?componente=ITA\&sequencial=1700759\&num_ registro $=201702446106 \&$ data $=20180523 \&$ formato $=$ PDF. Acesso em: 5 nov. 2019.

BRASIL. Superior Tribunal de Justiça (Corte Especial). Recurso especial 1704520/ MT. Recurso especial representativo de controvérsia. Direito processual civil. Natureza jurídica do rol do art. 1.015 do cpc/2015. Impugnação imediata de decisôes interlocutórias não previstas nos incisos do referido dispositivo legal. Possibilidade. Taxatividade mitigada. Excepcionalidade da impugnação fora das hipóteses previstas em lei. Requisitos. Recorrente: Quim Comercio de Vestuario Infantil Limitada ME. Recorrido: Shirase Franquias e Representacoes LTDA. Relatora: Min. Nancy Andrighi, 05 de dezembro de 2018. Disponível em: https:/ww2.stj.jus.br/processo/ revista $/$ documento/mediado/?componente=ITA\&sequencial=1731786\&num_ registro $=201702719246 \&$ data $=20181219 \&$ formato $=$ PDF. Acesso em: 5 nov. 2019.

BRASIL. Lei n. 13.105, de 16 de março de 2015. Institui o Código de Processo Civil de 2015. Brasília: Congresso Nacional, [2015]. Disponível em: http://www. planalto.gov.br/ccivil_03/_ato2015-2018/2015/lei/113105.htm. Acesso em: 12 out. 2019. 
BRASIL. Lei n. 12.016, de 7 de agosto de 2009. Disciplina o mandado de segurança individual e coletivo e dá outras providências. Brasília: Congresso Nacional, [2009]. Disponível em: http://www.planalto.gov.br/ccivil_03/_ato2007-2010/2009/lei/ 112016.htm. Acesso em: 5 nov. 2019.

DIDIER JR., F.; CUNHA, L. C. Curso de direito processual civil: meios de impugnação às decisóes judiciais e processo nos tribunais. 14. ed. Salvador: Juspodivm, 2016.

FERREIRA, W. S. Cabimento do agravo de instrumento e a ótica prospectiva da utilidade - o direito ao interesse na recorribilidade de decisóes interlocutórias. Revista dos Tribunais, Revista de Processo, São Paulo, n. 263. p. 193-203. jan. 2017. JAYME, F. G.; SANTOS, M. F. A irrecorribilidade das decisóes interlocutórias no projeto do novo código de processo civil. Revista da Faculdade de Direito da UFMG, Belo Horizonte, 2011. Disponível em: https://www.direito.ufmg.br/ revista/index.php/revista/article/view/128/119. Acesso em: 5 nov. 2019.

KOCHEM, R. O artigo 1.015 do CPC em destaque: O STJ e a construção jurídica. Revista Consultor Jurídico, 19 mar. 2018. Disponível em: https://www. conjur.com.br/2018-mar-19/ronaldo-kochem-artigo-1015-cpc-stj-construcaojuridica. Acesso em: 12 out. 2019.

MARINONI, L. G.; ARENHART, S. C.; MITIDIEIRO, D. Novo curso de processo civil: tutela dos direitos mediante procedimento comum. 2. ed. Sáo Paulo: Revista dos Tribunais, 2016.

MELLO, R. L. T. et al. O agravo de instrumento e o rol do art. 1.015 do novo CPC: taxatividade? Revista Migalhas, 8 mar. 2016. Disponível em: https://www. migalhas.com.br/dePeso/16,MI235291,81042-O+agravo+de+instrumento+e+o+ rol+do+art+1015+do+novo+CPC+taxatividade. Acesso em: 5 nov. 2019.

NEVES, D. A. A. Manual de direito processual civil volume único. 9. ed. Salvador: Juspodivm, 2017.

NUNES, D.; ARAGÃO, E. A.; BARBOSA, L. F. STJ, o agravo e a interpretação extensiva do artigo 1015 do novo CPC. Revista Consultor Jurídico. 8 fev. 2018. Disponível em: https://www.conjur.com.br/2018-fev-08/opiniao-stj-agravointerpretacao-artigo-1015-cpc. Acesso em: 12 out. 2019.

ROMÃO, P. F. Taxatividade do rol do artigo 1.015 do novo código de processo civil: Mandado de segurança como sucedâneo do agravo de instrumento. Revista da Escola Superior da Magistratura do Estado do Ceará. Ceará, 18 mar. 2016. 
Disponível em: http://revistathemis.tjce.jus.br/index.php/THEMIS/article/ viewFile/504/506. Acesso em: 5 nov. 2019.

THEODORO JÚNIOR, H. Curso de direito processual civil: teoria geral do direito processual civil, processo de conhecimento e procedimento comum. 47. ed. Rio de Janeiro: Forense, 2015. v. 3.

THEODORO JÚNIOR, H. et al. Novo CPC: fundamentos e sistematização. 2. ed. Rio de Janeiro: Forense, 2015.

TUCCI, J. R. C. Ampliação do cabimento do recurso de agravo de instrumento. Consultor Jurídico, 18 jul. 2017. Disponível em: https://www.conjur.com.br/2017jul-18/paradoxo-corte-ampliacao-cabimento-recurso-deagravo-instrumento. Acesso em: 30 out. 2019. 